\title{
Maternal Parenting Stress, Mother-Child Interaction Activities, Maternal Parenting Behaviors, and Preschoolers' School Readiness in Early Childhood: Longitudinal Effects on Children's Academic Ability at School Entry
}

\author{
Youn-Sun Won ${ }^{1}$, Hyun-Sim Doh ${ }^{2}$ \\ Ph. D., Department of Child Development \& Intervention, Ewha Womans University, Seoul, Korea ${ }^{1}$ \\ Emeritus Professor, Department of Child Development \& Intervention, Ewha Womans University, Seoul, Korea ${ }^{2}$

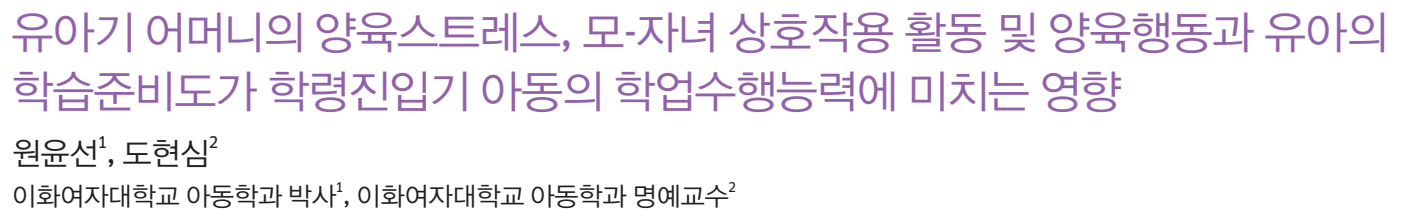

Objectives: The main purpose of this study was to explore the longitudinal effects of maternal parenting stress, mother-child interaction activities, maternal parenting behaviors, and preschoolers' school readiness on children's academic ability at school entry in early childhood.

Methods: This study used data from the seventh (T1) and eighth (T2) wave (2014 2015) of the Panel Study on Korean Children. The participants of this study were 942 between 6 and 7-year-old children and their mothers. Data analysis was performed using structural equation modeling.

Results: First, the relationship between maternal parenting stress and children's academic ability at school admission was sequentially mediated by mother-child interaction activities and preschoolers' school readiness. The higher the maternal parenting stress, the lower the mother-child interaction activities, and the lower the mother-child interaction activities, the lower the degree of preschoolers' school readiness. The poor degree of preschoolers' school readiness was related to the children's low academic ability at school entry. Second, the relationship between maternal parenting stress and children's academic ability at school entry was sequentially mediated by parenting behaviors and preschoolers' school readiness. The higher the maternal parenting stress, the less positive maternal parenting behaviors were, and the less positive maternal parenting behaviors were, the lower the level of preschoolers' school readiness, and the lower the children's academic performance at school entry. Conclusion: This study indicated that maternal parenting stress, mother-child interaction activities, maternal parenting behaviors, and preschoolers' school readiness in early childhood influenced firstgrade children's academic performance.

Keywords: parenting stress, mother-child interaction activities, parenting behaviors, school readiness, academic ability

Corresponding Author: Hyun-Sim Doh, Emeritus Professor, Department of Child Development \& Intervention, Ewha Womans University, 52, Ewhayeodae-gil, Seodaemun-gu, Seoul, 03760, Korea

E-mail: simdoh@ewha.ac.kr
(C)The Korean Association of Child Studies

This is an Open Access article distributed under the terms of the Creative Commons Attribution Non-Commercial License (http:// creativecommons.org/licenses/by-nc/4.0) which permits unrestricted noncommercial use, distribution, and reproduction in any medium, provided the original work is properly cited. 


\section{Introduction}

인간은 전 생애 발달과정에서 다양한 생태학적 전환을 경험하 게 된다. 특히 유아기에서 학령기로의 전환기를 지나 초등 1 학 년이 된 아동의 학습에 대한 흥미와 적절한 동기는 초등학교 생활뿐 아니라 중·고등학교에서의 학교생활에 대한 만족과 학업성취에도 영향을 미치므로(M. Kim, 2008) 이 시기 아동의 학업수행능력은 중요하게 다뤄져야 한다. 학업수행능력이란 학업을 수행하고 목표에 도달할 수 있는 결과에 초점이 맞춰 진 개념으로 아동이 언어 및 수리 영역 등에서 인지적으로 달 성할 수 있는 성취도를 의미한다(J. Kim \& Hong, 2019). 학업 수행능력은 갑자기 주어지는 능력이 아니라 발달적 맥락 속에 서 축적되는 것으로서 유아기 부모 역할은 매우 중요하다. 특 히, 주 양육자로서 유아와 대부분의 시간을 함께 보내며 가장 가까이에서 유아를 관찰할 수 있는 어머니의 역할은 꾸준히 많은 학문적 관심을 받아왔다. 따라서 학령진입기 아동의 학 업수행능력에 영향을 미치리라 예측되는 유아기 어머니의 양 육특성과 모-자녀 관계 변인들이 유아기 발달 및 초등학교 입 학 이후 아동의 학업수행능력에 영향을 미치는 단기 종단적 경로를 밝히는 연구가 필요하다.

본 연구에서는 초등학교 입학 직전인 만 6세 시기 어머니의 양육스트레스에 주목하는데, 이 시기는 유아기에서 학령기로 의 생태학적 전환기로서 이러한 전환기가 학령진입기 아동의 발달에 미치는 양육스트레스의 영향력을 확인할 수 있는 매 우 중요한 시점이기 때문이다. 그러나 자녀의 초등전환기 부 모의 양육스트레스가 학령진입기 아동의 학업수행능력에 미 치는 영향을 살펴본 종단 연구는 거의 발견하기가 어렵다. 이 에 영아기를 포함한 아동을 대상으로 한 연구들을 고찰해 보 면, 이와 관련하여 부모의 양육스트레스가 자녀의 학업수행 능력에 영향을 미치는 종단 연구들을 살펴보면, 먼저 15 개월 자녀를 둔 어머니의 양육스트레스가 이후 유치원 입학 시점 유아기 자녀의 어휘 및 학업 능력에 부정적 영향을 미쳤으며 (Harmeyer, Ispa, Palermo, \& Carlo, 2016), 걸음마기 자녀를 둔 아버지의 양육스트레스가 높을수록 훗날 3세 유아의 인지발 달 수준이 낮았다(Harewood, Vallotton, \& Brophy-Herb, 2016). 또한 만 6 세 자녀를 둔 어머니의 양육스트레스는 유아의 학업 능력을 낮추는 선행 변인으로 작용하였다(Lee, Oh, Yoo, Kwon, \& Noh, 2017).

부모의 양육스트레스 외에도, 부모와 자녀 간의 상호작용 활동 역시 유아의 발달에 영향을 미치는 주요 요인이다(J. H. $\mathrm{Kim}$, Jung, Kim, \& Yi, 2012). 부모-자녀 상호작용 활동이란 부
모가 자녀에게 책을 읽어주거나 함께 노래를 부르고 퍼즐이나 게임을 하는 등 부모가 자녀와 함께하는 실제 활동을 의미한 다. 부모-자녀 상호작용 활동과 학업수행능력 간의 관계를 살 펴본 선행 연구들에 의하면, 생후 3 년 동안의 양육자와 자녀 간 상호작용 활동이 학령기 및 청소년기 자녀의 어휘 및 수학 성 취도(Duncan, Schmitt, \& Vandell, 2019)에 긍정적 영향을 미쳤 고, 유아의 언어성과 동작성 지능(Erickson, Duvall, MacLean, Tonigan, Ohls, \& Lowe, 2018) 및 언어발달(S.-D. Park \& Chang, 2016)에도 긍정적 영향을 미쳤다. 그러나 부모와 자녀 간의 상 호작용 활동이 학업수행능력에 미치는 영향을 시간의 흐름에 따라 살펴본 국내 종단 연구는 특히 부족한 실정이다.

다음으로, 부모의 양육행동은 학업수행능력의 또 다른 선 행 변인 중 하나이다. 부모의 양육행동이 온정과 통제 모두 높 은 특성을 가질 때 권위 있는 부모로서 가장 바람직한 양육을 한다는 점에서(Baumrind, 1991), 이러한 양육을 긍정적 양육 행동으로 정의할 수 있다. 부모의 양육행동과 자녀의 학업수 행능력 간의 유의미한 경로를 보고한 종단 연구를 살펴보면, 2 세 때 주 양육자의 긍정적 양육행동은 7세 때 자녀의 높은 학 업 성적을 예측하였으며(Treyvaud, Doyle, Lee, Ure, Inder, Hunt, $\&$ Anderson, 2016), 어머니가 초기 3년 동안 영아기 자녀에게 긍정적 양육행동을 많이 할수록 영아의 언어발달 능력이 높게 측정되었다(M. Kim, Hu, \& Wang, 2019).

한편, 학령기 학업수행능력의 선행 변인에 관심을 둔 국내 외 연구자들에 따르면, 학업수행능력은 어머니의 양육스트레 스, 모-자녀 상호작용 활동 및 양육행동과 같은 부모 역할의 맥락에서 접근할 수 있을 뿐만 아니라, 유아 자신의 능력에 속 하는 학습준비도에 의해서도 직접적으로 영향을 받았다. 학 습준비도란 아동이 학교에서 효과적인 학습을 수행하고 성공 적으로 생활하는 데 필요한 기술과 인지적 및 정서적 발달을 모두 포함하는 개념이다(Akhtar \& Bilal, 2018). 국내외 다수의 선행 연구들은 유아기 학습준비도와 학령기 학업수행능력 간 의 종단적 연관성을 보고해 오고 있다(Bodovski \& Youn, 2011; Daviesa et al., 2016; J. Kim \& Hong, 2019; Y. Kim et al., 2019). 구체적으로는, 유아의 학습준비도가 초등 1 학년의 언어 및 수 리 학업 성취도(Murray \& Harrison, 2011)에 영향을 미쳤고, 54 개월 때 측정한 유아의 학습준비도가 초등 5학년의 학업성취 도를 예측하였다(Sabol \& Pianta, 2011). 그러나 국내의 경우 유 아기 가정환경과 학습준비도를 동시에 고려하여 학령진입기 아동의 학업수행능력에 미치는 영향을 살펴본 연구가 부족한 실정이므로 본 연구에서는 단기 종단 연구설계를 통해 변인들 간의 경로를 탐색하였다. 
앞서 살펴본 학업수행능력에 영향을 미치는 변인들로서 양 육스트레스, 부모-자녀 상호작용 활동 및 양육행동과 유아의 학습준비도는 또한 서로 밀접하게 관련된다. 어머니의 높은 양육스트레스는 모-자녀 상호작용에 부정적 영향을 미쳐 양 육스트레스가 높을수록 어머니들은 함께 노래 부르고, 책을 읽어주고, 레고나 블록과 같은 게임을 하는 등과 같은 상호작 용의 빈도가 낮았다(Farmer \& Lee, 2011). 양육스트레스와 양 육행동 간의 관계를 살펴보면, 어머니의 양육스트레스가 높을 수록 강압적이고 거부적 양육행동(M. S. Kim \& Moon, 2005) 과 권위주의적이고 통제적 양육행동(S. Y. Park, Chun, \& Han, 1996)을 많이 나타내었다. 부모의 양육스트레스와 유아의 학 습준비도 간의 관계에 관한 선행 연구는 매우 드문 편이나, 양 자 간의 부적인 관계가 일관되게 보고되고 있다(Jang, Kim, Lee, \& Kwon, 2018; Song, 2018).

모-자녀 상호작용 활동과 유아의 학습준비도 간의 관계 와 관련하여, 두 변인 간의 직접적 관계를 살펴본 국내외 선 행 연구는 부족한 실정이므로 부모-자녀 활동을 포함하는 부 모의 개입과 참여(Marti, Merz, Repka, Landers, Noble, \& Duch, 2018), 부모-자녀 의사소통과 대화(S. Kwon, K. Lee, 2018), 부 모-자녀 놀이 상호작용(Faith, Alison, Kenneth, Carol, \& Lenore, 1999)과 유아의 학습준비도 간의 관계를 통해 두 변인 간의 관 계를 예측할 수 있다. 부모의 양육행동 역시 학습준비도에 영 향을 미쳐 어머니의 부정적 양육행동은 유아의 낮은 학습준비 도와 관련되었으며(Dotterer, 2012), 신체적 처벌과 고함지르 기 및 꾸짖기 등의 심리적 공격을 하는 부모의 양육행동은 유 아의 학습준비도를 낮추는 선행 변인이었다(Weegar, GuérinMarion, Fréchette, \& Romano, 2018).

한편, 몇몇 선행 연구들은 앞서 살펴본 일부 변인들 간의 경 로를 보고하고 있다. 예를 들어, K. J. Park과 Kwon (2002)에 따 르면, 어머니의 양육스트레스가 모-자녀 상호작용에 부정적 영향을 미쳤으며, 부모-자녀 사이의 질적인 상호작용이 부족 할수록 유아의 학습준비도가 낮았다. 또한, 15 개월 걸음마기 자녀를 둔 어머니의 양육스트레스는 25 개월 자녀와 어머니 사이의 친밀한 상호작용을 방해하여 유치원 입학 직전 유아의 언어 및 학업 발달에 부정적 영향을 미쳤다(Harmeyera, Ispa, Palermo, \& Carlo, 2016). 한국아동패널 자료를 이용한 한 연구 에서도, 어머니의 양육스트레스가 초등학교 1학년 자녀의 학 업수행능력에 영향을 미치는 경로는 학습준비도에 의해 매개 되어, 만 4세 때 어머니의 양육스트레스가 높을수록 만 6세 유 아의 학습준비도 발달이 낮았고, 이는 초등 1 학년 아동의 낮은 학업수행능력을 초래하였다(Y. Kim, Koo, \& H. K. Kim, 2019).
이 외에도, 자녀가 14 개월 때 측정한 어머니의 양육스트레스 가 낮을수록 24 개월 때 어머니의 긍정적 양육행동이 높았고 이는 유치원 입학 직전 유아의 학업능력에 긍정적 영향을 미 쳤다(Palermo, Carlo, Ispa, \& Squires, 2019). 또한 만 5세 아동 과 어머니 217쌍을 대상으로 한 횡단 연구를 살펴보면 어머니 가 양육스트레스를 덜 지각할수록 온정적 양육행동을 더 많이 보였고 이는 유아의 학습준비도를 향상시키는 결과로 이어졌 다(Y. H. Song, 2018).

이와 같이, 연구변인들의 개별 및 매개적 관계를 보고하 는 선행 연구들에 기초하여, 본 연구는 학령 진입기 아동의 학업수행능력에 영향을 미치는 변인으로서 양육환경(Rydell, Berlin, \& Bohlin, 2003)과 유아의 학습준비도를 모두 고려하여 변인들 간의 경로를 탐색하는 연구모형을 설정함으로써 학령 진입기 아동의 학업수행능력에 영향을 미치는 변인 간의 구조 적 관계를 좀 더 심도 있고 통합적으로 살펴보고자 하였다. 이 와 동시에, 아동의 학업수행능력의 선행 변인들 가운데 선행 연구가 부족한 어머니의 양육스트레스, 모-자녀 상호작용 활 동 및 양육행동이 학업수행능력에 직접적으로 영향을 미치는 경로를 제외함으로써 변인들 간의 간접 경로를 탐색해보았다. 이러한 간접 경로는 어머니의 양육스트레스가 자녀의 학업수 행능력에 영향을 미친 것으로 나타난 국내외 선행 연구들에 근거한다. 또한 한국아동패널 자료를 이용한 연구 가운데 만 4 세 자녀를 둔 어머니의 양육스트레스가 만 7세 아동의 학업수 행능력에 영향을 미치는 간접 경로에서 만 6세 유아의 학습준 비도 및 전반적 양육환경의 질을 측정하는 만 5 세 유아의 가정 환경자극이 두 변인 간의 관계를 각각 완전 매개한 연구결과 (Y. Kim et al., 2019) 역시 이를 뒷받침해준다. 정리하면, 본 연 구는 어머니의 양육스트레스와 아동의 학업수행능력 간의 관 계에서 모-자녀 상호작용 활동 및 유아의 학업준비도의 순차 적 매개와 양육행동 및 유아의 학업준비도의 순차적 매개를 포함하는 경쟁모형을 설정하였다. 이러한 순차적 이중매개효 과는 단순매개효과에서는 충분히 설명하지 못하는 변인들 간 의 연속적이고도 복합적인 영향을 탐색할 수 있도록 돕는다. 이에 본 연구는 연구모형과 경쟁모형 가운데 어떤 모형이 변 인들의 구조적 관계를 좀 더 잘 설명하는지를 비교·검증해보 았다.

종합하면, 본 연구에서는 유아기 어머니의 양육스트레스 (T1), 모-자녀 상호작용 활동(T1), 어머니의 양육행동(T1), 유 아의 학습준비도(T1) 및 학령진입기 아동의 학업수행능력 (T2) 간의 관계를 연구모형과 경쟁모형을 설정하여 탐색하였 다(Figure 1). 


\section{연구문제1}

유아기 어머니의 양육스트레스, 모-자녀 상호작용 활동 및 어 머니의 양육행동과 유아의 학습준비도는 학령진입기 아동의 학업수행능력에 어떠한 경로로 영향을 미치는가?

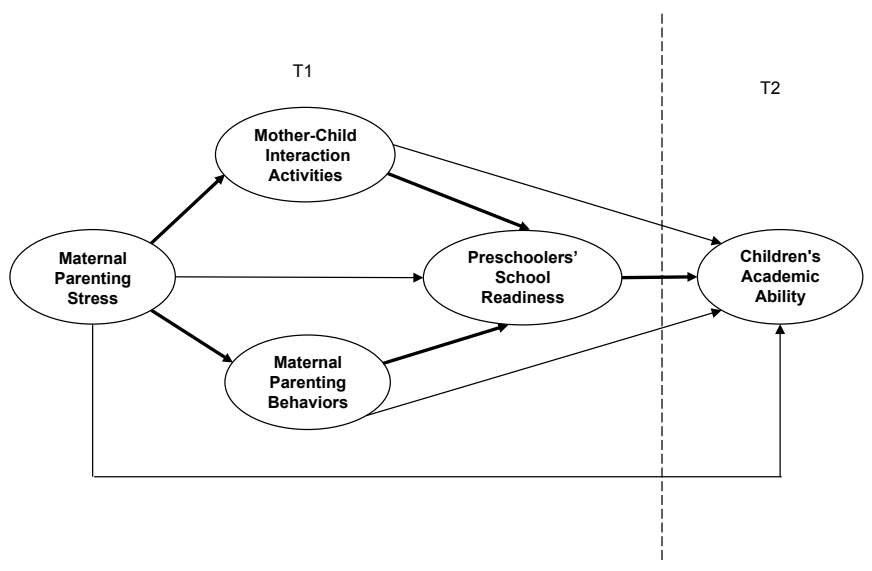

Figure 1. Research model: Direct and indirect paths connecting maternal parenting stress, mother-child interaction activities, maternal parenting behaviors, and preschoolers' school readiness to children's academic ability.

Note. Bold paths represent sequential mediation in the competition model.

\section{Methods}

\section{연구참가자}

본 연구의 참가자는 한국아동패널(Panel Study on Korean Children [PSKC]) 자료 중 2014년도(7차년도, T1) 및 2015년 도(8차년도, T2) 조사에서 본 연구변인들에 대해 모두 응답한 942가구의 만 6세(T1)와 만 7세(T2) 아동과 그들의 어머니다. 한국아동패널은 2008 년도에 실시된 1차년도 조사를 시작으 로 2027년까지 총 20년간 이루어지는 장기종단 연구 자료다. 연구 참가자의 사회인구학적 특성을 $\mathrm{T} 1$ 기준으로 살펴보면, 아동의 성별은 남아가 485 명(51.5\%), 여아가 457명(48.5\%) 이었고, 어머니의 연령은 35-39세가 471명(50.0\%)으로 가장 많았고, 30-34세가 245명(26.1\%), 40-49세가 206명(21.8\%), 25-29세가 15 명(1.5\%), 50세 이상이 4명 $(0.4 \%)$ 이었다. 또한 어머니의 학력은 4 년제 대학교 졸업이 326 명(34.6\%), 전문대 졸업이 285명(30.3\%), 고등학교 졸업이 282명(29.9\%), 대학 원 졸업이 45 명 $(4.8 \%)$ 순이었다. 어머니의 취업 및 학업 상태
는 미취업/미취학인 경우가 494명(52.4\%)로 가장 많았고, 취 업중인 경우는 401명(42.6\%), 취업/학업 병행인 경우는 29명 (3.1\%), 학업중인 경우는 8 명 $(0.8 \%)$ 으로 조사되었다. 가정의 사회경제적 수준과 관련하여 7 차년도 $(\mathrm{T} 1,2014)$ 월 평균 가구 소득의 평균은 438.13만원, 표준편차는 193.28만원이었고, 8 차년도(T2, 2015) 월 평균 가구소득의 평균은 458.08만원, 표 준편차는 204.76만원이었다.

\section{연구도구}

\section{어머니의 양육스트레스}

양육스트레스 척도는 K. H. Kim과 Kang (1997)이 개발한 것 으로서 한국아동패널 연구진이 하위 요인 중 부모역할 수행 에 대한 부담감 및 디스트레스를 발췌하여 예비조사를 통 해 확정한 총 11 문항으로 구성되어 있다. 이 척도는 5점 리커 트 척도로 어머니에 의해 측정되었으며, 문항 간 내적 합치도 (Cronbach's $\alpha$ )는 .88이었다.

\section{모-자녀 상호작용 활동}

모-자녀 상호작용 활동 척도는 Early Childhood Longitudinal Study Kindergarten Cohort (ECLS-K)의 Home Environment, Activities, And Cognitive Stimulation (HEQ) 중 모-자녀 상호작 용 활동을 질문하는 총 9문항으로 구성되어 있다. 이 척도는 한국아동패널 연구진이 번역한 뒤, 제 3자에 의해 역 번역한 내용을 Early Childhood Longitudinal Studies (ECLS)로부터 확 인 후 사용 허가를 취득한 것이다. 이 척도는 각 문항에 대하여 지난 일주일동안 모-자녀 상호작용 활동의 정도를 어머니가 응답하도록 되어 있으며 $(1=$ 전혀 하지 않음 $4=$ 매일 함), 문 항 간 내적 합치도(Cronbach's $\alpha$ )는 .83이었다.

\section{어머니의 양육행동}

양육행동 척도는 Cho, Lee, Lee와 Kwon (1999)이 개발한 문항 을 참고하여 한국아동패널 연구진이 자체 제작한 것이다. 본 연 구에서는 어머니의 긍정적 양육행동을 온정과 통제(Baumrind, 1991)를 모두 포함한 통합된 개념으로 정의내리고 이를 단일 요 인으로 구성하였다(총 12 문항). 이와 관련하여, 통제에 해당하 는 한 문항 “나는 아이가 내 말에 순종하도록 한다." 을 삭제하 였는데, 그 이유는 해당 문항이 안면타당도 측면에서 부정적 의 
미를 내포하는 심리적 통제에 해당하기 때문이다(C.-I. Kim \& Kwon, 2018; E. J. Lee \& Doh, 2020). 따라서 점수가 높을수록 긍 정적, 즉 민주적 양육행동 수준이 높음을 의미한다. 이 척도는 어머니에 의해 측정되었으며, 5점 리커트 척도로 구성된다. 문 항 간 내적 합치도(Cronbach's $\alpha$ )는 .79이었다.

유아의 학습준비도

유아의 학습준비도 척도는 Murphey와 Burns (2002)가 제작한 학습준비도 측정도구를 한국아동패널 연구진이 번역한 뒤 예 비조사를 수행하여 구성한 것이다. 이 척도는 사회 정서 발달 (6문항), 학습에 대한 태도(8문항), 의사소통(3문항), 인지발달 및 일반적 지식(5문항)의 네 가지 하위영역으로 이루어져 있 다(총 22문항). 이 척도는 4점 리커트 방식으로 어머니에 의해 측정되었으며, 각 하위영역의 문항 간 내적 합치도(Cronbach's $\alpha$ )는 사회 정서 발달은 .75 , 학습에 대한 태도는 .87 , 의사소통 은 .87 , 인지 발달 및 일반적 지식은 .81 이었다.

\section{학령진입기 아동의 학업수행능력}

아동의 학업수행능력은 E. Lee 등 (2008)이 제작한 도구에 의 해 측정되었다. 국어와 수학 각각 4 문항과 5 문항으로 구성된 다(총 9문항). 각 문항은 하위 $20 \%$ 이내(1점), 하위 $21-40 \%(2$ 점), 중간 $50 \%$ 내외(3점), 상위 $21-40 \%$ (4점), 상위 $20 \%$ 이내(5 점)의 5점 리커트 척도로 담임교사에 의해 측정되었다. 각 하 위영역의 문항 간 내적 합치도(Cronbach's $\alpha$ )는 국어는 .94, 수 학은 .98 이었다.

\section{자료분석}

본 연구는 연구모형 및 경쟁모형의 타당성과 변인들 간의 경 로를 분석하기 위해 AMOS 23.0 (IBM Co., Armonk, NY) 프로 그램을 사용하여 구조방정식모형(Structural Equation Modeling $[\mathrm{SEM}])$ 을 검증하였다. 연구의 잠재변인이 적합한 측정변인들 로 구성되었는지 확인하기 위해 모형 적합도, 요인부하량, 잠 재변인 간의 상관계수를 구하고 확인적 요인분석(Confirmatory Factor Analysis [CFA])을 시행하여 측정모형을 검증하였다. 측정 모형 및 구조모형의 적합도 판별은 절대적 적합지수인 $\chi^{2}$ 검증 과 NFI, IFI, CFI, TLI, RMSEA 지수를 고려하여 적합도를 평가 하였다. 간접효과 유의성을 확인하기 위해 부트스트랩 신뢰도 구간(bootstrapped confidence interval) 검증을 실시하였다. 또한
개별매개효과의 유의성은 팬텀 분석으로 확인하였고, 구조모 형 검증 시 아동의 성별과 가정의 사회경제적 수준이 각각 연구 변인들에 미치는 영향을 보고한 선행 연구들(Yoon et al., 2017; Anderson, 2015)에 근거하여 이를 통제하였다.

\section{Results}

\section{예비 분석}

Table 1에 제시한 바와 같이, 왜도는 -1.43 .67, 첨도는 -.43 3.36 으로 나타나 모든 변인들이 정규성 문제가 없음을 확인하 였다. 다음으로, Pearson의 상관분석을 실시한 결과, 유아기 어 머니의 양육스트레스와 학령진입기 아동의 학업수행능력의 하위요인 중 국어 간의 관계를 제외하고는 변인들 간의 상관관 계가 모두 유의하였다 $(r s=-.39 \sim .97, p<.05$ 혹은 $p<.01$ 혹은 $p<.001)$. 통제변인의 경우, $\mathrm{T} 1$ 의 사회경제적 수준은 어머니 의 양육스트레스 $(r=-.15, p$ <.001), 모-자녀 상호작용 활동 $(r=$ $.09, p<.01)$ 및 유아의 학습준비도 $(r=.08, p<.05)$ 와, T2의 사 회경제적 수준은 학령진입기 아동의 학업수행능력 $(r=.09, p<$ .01)과 유의한 상관관계를 나타내었다. 즉, 소득이 높을수록 어 머니의 양육스트레스는 낮았고, 모-자녀 상호작용 활동, 유아 의 학습준비도 및 학령진입기 아동의 학업수행능력이 높았다. 또한, 학습준비도 $(t=-3.60, p<.001)$ 와 학업수행능력 $(t=-5.45$, $p<.001)$ 에서 아동의 성별에 따른 유의한 차이가 나타나, 여아 가 남아보다 학습준비도와 학업수행능력이 더 높았다.

\section{측정모형의 분석}

측정모형을 검증하기에 앞서 어머니의 양육행동은 조작적 정 의에 의해 2 개의 하위영역인 온정과 통제가 모두 높은 것을 긍 정적 양육행동으로 정의내리고 이를 단일요인으로 구성하였 다. 이와 더불어 어머니의 양육스트레스와 모-자녀 상호작용 활동 역시 단일요인으로 구성되어 타당도를 검증할 수 없기 때문에 Russell, Kahn, Spoth와 Altmaier (1998)이 제시한 문항 꾸러미(Item Parcel) 방법을 적용한 후 타당도를 검증하였다(S. $\mathrm{Kim}, 2016)$. 문항 꾸러미 방법에서는 측정변인이 각 문항의 평 균이나 합으로 이루어지므로 신뢰도가 상승하며 추정해야 하 는 모수가 감소하여 측정오차가 낮아지고 모형의 적합도가 개 선된다(Bae, 2018). 문항 꾸러미 제작은 어머니의 양육스트레 스(11문항), 모-자녀 상호작용 활동(9문항), 어머니의 양육행 
동(11문항)에서 추출할 요인을 1 로 고정하여 탐색적 요인분석 을 실시하였다. 그 결과 나타난 요인행렬표에 따라 요인부하 량이 가장 큰 문항부터 작은 순서대로 첫 줄은 좌측부터, 다음 줄은 우측부터 시작하여 지그재그 방식으로 3 개의 꾸러미로 정렬하였다(S. Kim, 2016). 측정모형의 확인적 요인분석을 실 시한 결과 적합도는 $\chi^{2}=367.19(d f=80, p<.001), \mathrm{NFI}=.956$, $\mathrm{IFI}=.965, \mathrm{CFI}=.965, \mathrm{TLI}=.954, \mathrm{RMSEA}=.062(90 \% \mathrm{CI}[.055$, .068])로 양호하게 나타나 적합한 모형임을 확인하였다. 측정 변인에 대한 잠재변인의 요인 부하량은 어머니의 양육스트레 스는 .83 .90, 모-자녀 상호작용 활동은 .73 .85, 어머니의 양 육행동은 . $74 \sim .83$, 유아의 학습준비도는 .71 .88, 학령진입 기 아동의 학업수행능력은 .92 .96으로 나타나 모든 요인 부 하량이 최소 기준인 .40이상(G.-S. Kim, 2010)으로 확인되어 측정모형이 타당함을 확인하였다.

\section{구조모형의 분석}

\section{연구모형과 경쟁모형의 적합도 분석}

본 연구는 연구모형과 경쟁모형을 설정하였으며, 두 모형을 비교·검증하기 위하여 모형의 적합도 지수를 살펴보았다. 연 구모형의 적합도 지수는 $\chi^{2}=548.45(d f=121, p<.001), \mathrm{NFI}=$ $.942, \mathrm{IFI}=.955, \mathrm{CFI}=.954, \mathrm{TLI}=.942, \mathrm{RMSEA}=.061$ 으로 연 구모형의 구조모형은 적합한 것으로 확인되었다. 경쟁모형의 적합도 지수는 $\chi^{2}=553.39(d f=125, p<.001), \mathrm{NFI}=.942, \mathrm{IFI}=$ $.954, \mathrm{CFI}=.954, \mathrm{TLI}=.944, \mathrm{RMSEA}=.060$ 로 경쟁모형의 구 조모형 역시 적합한 것으로 확인되었다. 연구모형과 경쟁모형 중 더 적합한 모형을 판별하기 위하여 카이제곱차이 검증을 실시한 결과, $\Delta \chi^{2}(4)=4.94, n . s$ 로 유의수준 .05 에서 두 모형의 적합도의 차이는 유의미하지 않은 것으로 나타났다. 구조방정 식 모형에서 자유도는 모형의 간명성을 나타내는데(S. Hong, 2000), 간명한(parsimonious) 모형이란 적합도를 최대한 좋게 하면서 단순화한 모형을 의미한다(S. Hong, 2000). 두 모형 간 에 유의한 차이가 없을 경우 보다 간명한 모형을 선택하는 것 이 권장된다는 점에서(S. Hong, 2009), 본 연구는 연구모형(df $=121)$ 보다 자유도가 더 큰 경쟁모형 $(d f=125)$ 이 변인들의 구 조적 관계를 좀 더 잘 설명해주는 더 적합한 모형으로 판단하 였다. 또한 연구모형의 경로계수를 검토한 결과 어머니의 양 육스트레스와 모-자녀 상호작용 활동 및 양육행동이 각각 학 업수행능력에 이르는 직접경로와 양육스트레스가 유아의 학 습준비도에 이르는 직접 경로가 모두 유의하지 않아 자료의
설명력이 덜하다고 볼 수 있다. 따라서 순차적 이중매개만을 포함한 간접 경로를 설정한 경쟁모형이 자료에 더 부합되며 변인들 간의 관계를 좀 더 명확히 설명해주는 더 적합한 모형 이므로 본 연구에서는 경쟁모형을 최종모형으로 선택하였다.

\section{최종모형의 분석}

최종모형의 경로계수 검증 결과를 Figure 2에 제시하였다. 아 동의 성별은 독립표본 $t$-검정 결과에 따라 유아의 학습준비도 와 학령진입기 아동의 학업수행능력을 통제하였고, 7차년도 월 평균 가구소득(T1)은 상관분석 결과에 따라 어머니의 양육 스트레스, 모-자녀 상호작용 활동, 유아의 학습준비도를 통제 하였고, 8차년도 월 평균 가구소득(T2)은 학령진입기 아동의 학업수행능력을 통제하였다. 유아기 어머니의 양육스트레스 가 학령진입기 아동의 학업수행능력에 이르는 두 가지 간접 경로에서 각 변인 간의 직접경로 계수를 살펴보면 다음과 같 다. 먼저, 양육스트레스, 모-자녀 상호작용 활동, 유아의 학습 준비도 및 학업수행능력 간의 경로와 관련하여, 어머니의 양 육스트레스는 모-자녀 상호작용 활동 $(\beta=-.34, p<.001)$ 에, 모자녀 상호작용 활동은 유아의 학습준비도 $(\beta=.09, p<.05)$ 에, 그리고 유아의 학습준비도는 학령진입기 아동의 학업수행능 력 $(\beta=.24, p<.001)$ 에 유의한 영향을 미쳤다. 즉, 어머니의 양 육스트레스가 높을수록 모-자녀 상호작용 활동이 낮았고, 모자녀 상호작용 활동이 낮을수록 유아의 학습준비도가 낮았으 며, 낮은 유아의 학습준비도는 학령진입기 아동의 학업수행능 력을 낮췄다. 다음으로, 양육스트레스, 양육행동, 학습준비도 및 학업수행능력 간의 경로와 관련하여, 어머니의 양육스트레 스는 양육행동 $(\beta=-.47, p<.001)$ 에, 양육행동은 유아의 학습 준비도 $(\beta=.32, p<.05)$ 에, 그리고 유아의 학습준비도는 학령 진입기 아동의 학업수행능력 $(\beta=.24, p<.001)$ 에 유의한 영향 을 미쳤다. 즉, 어머니의 양육스트레스가 높을수록 양육행동 은 덜 긍정적이었고, 긍정적 양육행동이 덜 나타날수록 유아 의 학습준비도가 낮았으며, 학습준비도가 낮을수록 학령진입 기 아동의 학업수행능력이 낮게 측정되었다.

다음으로, 잠재변인 간의 구조적 관계를 구체적으로 확인하 기 위하여 부트스트래핑(Bootstrapping) 방법을 사용하여 직접 효과, 간접효과 및 총효과를 살펴보았고 그 결과를 Table 2에 제 시하였다. 간접효과의 경우, 어머니의 양육스트레스가 학령진 입기 아동의 학업수행능력에 미치는 간접경로는 유의하였다. 총효과와 관련하여, 학령진입기 아동의 학업수행능력에 가장 큰 영향을 미치는 변인은 유아의 학습준비도 $(\beta=.24, p<.001)$ 
Table 1

Correlation Coefficients Among Variables

\begin{tabular}{|c|c|c|c|c|c|c|c|c|c|c|c|}
\hline & 1 & 2 & 3 & 4 & $4-1$ & $4-2$ & $4-3$ & $4-4$ & 5 & $5-1$ & $5-2$ \\
\hline 1. MPS(T1) & - & & & & & & & & & & \\
\hline 2. $\mathrm{MIA}(\mathrm{T} 1)$ & $-.29^{* * *}$ & - & & & & & & & & & \\
\hline 4. $\operatorname{PSR}(\mathrm{T} 1)$ & $-.23^{* * *}$ & $.20^{* * *}$ & $.29^{* * *}$ & - & & & & & & & \\
\hline 4-1. SED & $-.25^{* * *}$ & $.15^{* * *}$ & $.23^{* * *}$ & $.82^{* * *}$ & - & & & & & & \\
\hline 4-3. Communication & $-.16^{* * *}$ & $.13^{* * *}$ & $.24^{* * *}$ & $.84^{* * *}$ & $.56^{* * *}$ & $.72^{* * *}$ & - & & & & \\
\hline 4-4. CDGK & $-.14^{* * *}$ & $.17^{* * *}$ & $.25^{* * *}$ & $.84^{* * *}$ & $.53^{* * *}$ & $.70^{* * *}$ & $.74^{* * *}$ & - & & & \\
\hline 5. CAA(T2) & $-.07^{*}$ & $.07^{*}$ & $.11^{* * *}$ & $.25^{* * *}$ & $.14^{* * *}$ & $.25^{* * *}$ & $.18^{* * *}$ & $.28^{* * *}$ & - & & \\
\hline 5-1. KL & -.06 & $.07^{*}$ & $.10^{* *}$ & $.25^{* * *}$ & $.13^{* * *}$ & $.25^{* * *}$ & $.19^{* * *}$ & $.27^{* * *}$ & $.97^{* * *}$ & - & \\
\hline 5-2. Mathematics & $-.07^{*}$ & $.07^{*}$ & $.12^{* * *}$ & $.24^{* * *}$ & $.14^{* * *}$ & $.24^{* * *}$ & $.17^{* * *}$ & $.26^{* * *}$ & $.97^{* * *}$ & $.88^{* * *}$ & - \\
\hline$S D$ & 6.76 & 4.59 & 4.49 & 7.85 & 2.34 & 3.30 & 1.44 & 1.96 & 7.98 & 3.88 & 4.35 \\
\hline Skewness & .24 & .67 & -.38 & -.80 & -.55 & -.65 & -.94 & -1.40 & -1.27 & -1.12 & -1.43 \\
\hline Kurtosis & .16 & 1.03 & 1.79 & .22 & -.43 & -.23 & .13 & 3.36 & 1.17 & .55 & 1.79 \\
\hline
\end{tabular}

Note. $N=$ 942. MPS = Maternal parenting stress; MIA = Mother-child interaction activities; MPB = Maternal parenting behaviors; PSR = Preschooler's school readiness; SED = Social and emotional development; $\mathrm{AL}=$ Approach to learning; CDGK = Cognitive development and general knowledge; CAA = Children's academic ability; KL = Korean Language; SES = Socioeconomic status. ${ }^{*} p<.05 .{ }^{* *} p<.01 .{ }^{* * *} p<.001$.

Figure 2. Final model: Sequential mediation in the indirect paths of maternal parenting stress to children's academic ability. ${ }^{*} p<.05$. ${ }^{* * *} p<.001$. 
Table 2

Direct, Indirect, and Total Effects in the Final Model

\begin{tabular}{|c|c|c|c|}
\hline Path of latent variables & Direct & Indirect & Total \\
\hline Maternal parenting stress(T1) $\rightarrow$ Mother-child interaction activities(T1) & $-.34^{* * *}$ & - & $-.34^{* *}$ \\
\hline Maternal parenting stress(T1) $\rightarrow$ Maternal parenting behaviors(T1) & $-.47^{* * *}$ & - & $-.47^{* *}$ \\
\hline Maternal parenting stress(T1) $\rightarrow$ Children's academic ability(T2) & - & $-.04^{* * *}$ & $-.04^{* * *}$ \\
\hline Mother-child interaction activities(T1) $\rightarrow$ Preschooler's school readiness(T1) & $.09^{*}$ & - & $.09^{*}$ \\
\hline Maternal parenting behaviors $(\mathrm{T} 1) \rightarrow$ Preschooler's school readiness $(\mathrm{T} 1)$ & $.32^{* * *}$ & - & $.32^{* * *}$ \\
\hline Maternal parenting behaviors(T1) $\rightarrow$ Children's academic ability(T2) & - & $.08^{* * *}$ & $.08^{* * *}$ \\
\hline Preschooler's school readiness $(\mathrm{T} 1) \rightarrow$ Children's academic ability(T2) & $.24^{* * *}$ & - & $.24^{* * *}$ \\
\hline
\end{tabular}

$\mathrm{R}^{2} \quad$ Mother-child interaction activities $=.124$, Maternal parenting behaviors $=.217$ Preschooler's school readiness $=.138$,

Children's academic ability $=.111$

Note. $N=942$.

${ }^{*} p<.05 .{ }^{* * *} p<.001$.

이었으며, 그 다음은 어머니의 양육행동 $(\beta=.08, p<.001)$ 으로 나타났다. 다중상관자승(Squared Multiple Correlations [SMC]) 지표인 R제곱을 살펴본 결과, 어머니의 양육스트레스는 모-자 녀 상호작용 활동을 $12.4 \%$, 어머니의 양육행동을 $21.7 \%$ 설명 하였고, 모-자녀 상호작용 활동과 어머니의 양육행동은 유아의 학습준비도를 $13.8 \%$ 설명하였다. 또한 유아의 학습준비도는 학령진입기 아동의 학업수행능력을 $11.1 \%$ 설명하였다.

이어서, 유아기 어머니의 양육스트레스가 학령진입기 아동 의 학업수행능력에 이르는 개별 간접효과의 통계적 유의도 추 정을 위하여 팬텀분석을 실시하였다. 어머니의 양육스트레스 가 모-자녀 상호작용 활동과 유아의 학습준비도를 순차적으 로 거쳐 학령진입기 아동의 학업수행능력에 영향을 미치는 개 별 간접효과가 유의하였다 $(\mathrm{B}=-.01, p<.05)$. 또한, 어머니의 양육스트레스가 어머니의 양육행동과 유아의 학습준비도를 순차적으로 거쳐 학령진입기 아동의 학업수행능력에 영향을 미치는 개별 간접효과가 유의하였다 $(\mathrm{B}=-.07, p<.001)$.

\section{Discussion}

본 연구는 육아정책연구소에서 수행하는 한국아동패널의 7,8 차년도 자료를 이용하여, 유아기 어머니의 양육스트레스, 모-자 녀 상호작용 활동 및 양육행동과 유아의 학습준비도가 학령진 입기 아동의 학업수행능력에 미치는 영향을 살펴보는 것을 주 목적으로 하였다. 본 연구는 변인들 간의 구조적 관계를 명확히
설명해주는 좀 더 적합한 모형을 선택하기 위해 연구모형과 경 쟁모형을 설정하였고, 그 결과 경쟁모형이 모형의 간명성 및 이 론적, 통계적 측면에서 더 적합한 것으로 판단되어 경쟁모형을 최종모형으로 채택하였다. 그 결과, 유아기 어머니의 양육스트 레스는 학령진입기 아동의 학업수행능력에 직접적 영향을 미치 기보다 모-자녀 상호작용 활동 혹은 양육행동과 유아의 학습준 비도의 순차적 매개를 통해 간접적으로 영향을 미침을 확인하 였다. 두 가지 간접 경로에 관해 각각 논의하면 다음과 같다.

먼저, 유아기 어머니의 양육스트레스, 모-자녀 상호작용 활 동 및 유아의 학습준비도가 학령진입기 아동의 학업수행능력 에 영향을 미치는 간접 경로와 관련하여, 어머니의 양육스트 레스가 높을수록 모-자녀 상호작용 활동은 낮았고, 모-자녀 상 호작용 활동이 낮을수록 유아의 학습준비도가 낮았으며, 낮은 수준의 학습준비도는 학령진입기 아동의 낮은 학업수행능력 으로 연결되었다. 이로써, 본 연구는 자녀의 유치원 시기에 어 머니가 겪는 양육스트레스가 초등 1학년 시기의 학업수행능력 에 영향을 미치는 경로에서 모-자녀 상호작용 활동 및 학습준 비도의 이중매개효과를 확인하였다. 이러한 연구결과는 어머 니의 양육스트레스가 1년 뒤 모-자녀 상호작용을 감소시켜 유 아의 학습준비도가 낮아졌다는 한국아동패널 자료를 사용한 종단 연구의 결과(Y.-M. Kim, 2019)와 부분적으로 일치한다.

본 연구의 간접경로와 관련해서는 선행 연구가 매우 부족 하여, 두 변인 간의 관계를 살펴본 연구들과 비교하여 설명할 수 있다. 이러한 연구결과는 한국아동패널 자료를 사용하여 부 모-자녀 상호작용과 학습준비도 간의 정적인 관계를 보고한 
횡단 연구결과(Y. Lee et al., 2018) 및 학습준비도가 학업수행능 력에 미치는 영향을 보고한 연구결과(J. Kim \& Hong, 2019)와 부분적으로 일치한다. 또한 국외 종단 연구결과(Daviesa et al., 2016) 역시 본 연구결과와 부분적으로 일치한다. 이러한 연구 결과는 가족 구성원 사이의 상호작용 및 부모-자녀관계가 초 등학교 입학준비를 위해 중요한 역할을 하며(Anderson, 2015) 초기 학교적응에 유의미한 영향을 미친다고 주장한 연구결과 (Bardack et al., 2017)와도 유사한 맥락에서 이해할 수 있다. 부 모의 양육스트레스가 낮을수록 부모는 자녀와 함께 적극적으 로 상호작용 활동을 하기 쉬우며, 이러한 과정에서 아동은 중 요한 타인인 부모와의 애착을 형성하고 정서적 교감을 나누는 경험을 바탕으로 의사소통 능력과 과제 수행력 등을 향상시킬 수 있을 것이다. 따라서 유아기와 초등 전환기에 학업수행능 력의 선행 변인인 유아기 어머니의 양육스트레스를 낮출 뿐만 아니라 모-자녀 상호작용 활동을 증가시킴으로써 유아의 사 회·정서발달 및 의사소통능력과 인지발달 수준의 지표가 되는 학습준비도를 향상시키고 나아가 학령 초기 아동의 학업수행 능력을 향상시키기 위해 노력을 기울여야 할 것이다.

다음으로, 유아기 어머니의 양육스트레스, 양육행동 및 유 아의 학습준비도가 학령진입기 아동의 학업수행능력에 영향을 미치는 간접 경로와 관련하여, 어머니의 양육스트레스가 높을 수록 양육행동이 덜 긍정적이었으며, 긍정적 양육행동을 덜 나 타낼수록 유아의 학습준비도가 낮았으며, 학습준비도가 낮을 수록 학령진입기 아동의 학업수행능력이 낮게 측정되었다. 이 로써 양육스트레스가 학업수행능력에 이르는 경로에서 양육행 동과 학습준비도의 이중매개효과가 확인되었다. 해당 경로의 모든 변인들을 동시에 포함한 연구를 발견하기 어려워, 본 연구 결과는 일부 변인 간의 관계를 밝힌 선행 연구결과와 비교해볼 수 있다. 이러한 결과는 양육스트레스가 낮을수록 긍정적 양육 행동이 높아져 궁극적으로 학습준비도를 향상시킨다는 연구결 과(Song, 2018)과 부분적으로 일치한다. 또한, 본 연구결과는 부 모의 긍정적 양육행동과 유아의 학습준비도 간의 직접적 관련 성을 보고한 국내외 선행 연구결과들(Song, 2018; Prendergast \& MacPhee, 2018)과 동일한 맥락에서 이해할 수 있다.

무엇보다도, 본 연구에서 유아기 어머니의 양육스트레스가 1 년 뒤 초등 1 학년이 된 학령진입기 아동의 학업수행능력에 영향을 미친 점은 유아기 어머니의 양육스트레스에 대한 단기 종단적 영향력을 밝혔다는 측면에서 주목할 만하다. 특히 우 리나라의 경우에는 과열된 교육열을 비롯하여 맞벌이 부부의 증가, 가사 및 육아분담의 어려움, 취업모의 일과 가정의 양립 유지의 어려움 등으로 양육스트레스가 과중될 가능성이 높은
사회적 환경에 처해 있다. 따라서 유아기 어머니의 양육스트 레스에 대한 사회적 관심과 지원이 요구되며 부모 스스로 이 를 적절히 다루고 조절할 수 있도록 예방 차원의 부모교육프 로그램이 개발되고 실시되어야 할 것이다.

또한 어머니의 양육행동은 양육스트레스가 학업수행능력 에 영향을 미치는 간접경로에서 매개역할을 하였다. 이는 아 동의 인지발달을 이해하는 데 있어 어머니의 양육행동과 같은 부모의 양육특성과 가족의 맥락이 매우 중요함을 의미한다. 이처럼 양육행동은 아동발달에 영향을 미치는 중요한 선행 변 인으로 작용해왔으며, 이러한 부모의 양육행동은 아동의 현재 의 발달뿐 아니라 장래의 발달에 이르기까지 중대한 영향을 미치는 것으로 보고된다는 점에서(도현심, 김민정, 박보경, 황 영은, 2005) 그 중요성을 간과해서는 안 될 것이다.

더불어, 아동의 학업수행능력의 선행 변인으로서 유아의 학 습준비도는 유아기 가정환경과 학령진입기 아동의 학업수행능 력을 연결하는 완전매개변인으로서 중요한 역할을 하였다. 즉, 학습준비도는 학업수행능력에 직접적 영향을 미치는 유일한 선행 변인으로서, 양육스트레스와 모-자녀 상호작용 활동 및 양육행동과 같은 부모의 양육특성 변인들은 학습준비도를 통 해서만 학업수행능력에 간접적으로 영향을 미쳤다. 특히 학습 준비도의 하위요인 중 하나인 사회·정서발달에 주목할 필요가 있는데, 이는 학업수행능력의 증진을 위해서는 인지.학습적인 발달뿐 아니라 또래관계, 정서인식 및 정서조절과 규칙준수 등 의 전반적인 사회성을 포함하는 사회정서 발달이 매우 중요함 을 의미한다. 학습준비도와 학업수행능력 간의 종단적 인과관 계를 밝힌 다수의 연구결과들(Bodovski \& Youn, 2011; Daviesa et al., 2016)이 강조하듯이, 유아기의 학습준비도는 학업지연과 학 교부적응 등의 문제를 비롯하여 초등 저학년 시기부터 나타날 수 있는 학습격차와 학업중단을 예방하는 데 도움이 될 것이다.

본 연구의 제한점과 후속 연구를 위한 제언은 다음과 같다. 첫째, 본 연구는 한국아동패널의 자료를 이용함으로써 연구대 상 및 척도의 선정에 다소의 제한이 있었다. 후속 연구에서는 평정자의 주관적 평가와 측정 오류를 최소화하기 위하여 어머 니와 교사뿐 아니라 아버지와 아동 등을 참여시킴으로써 연구 의 객관성을 확보할 수 있을 것이다. 둘째, 본 연구에서는 초등 학교 입학 직전인 만 6세 유아와 초등 1학년 아동만을 대상으 로 총 2 개년도의 종단 자료를 이용함으로써, 유아기 전반에 걸 친 양육특성과 초등학교 입학 이후 초등 저학년 또는 고학년 까지 폭넓게 아우르는 자료를 확보하지 못하였다. 따라서 후 속 연구에서는 다양한 연령을 대상으로 장기 종단 연구를 수 행하는 것이 바람직할 것이다. 이외에도, 본 연구는 아동발달 
에 영향을 미치는 양육특성을 포함한 가정환경 변인을 측정하 는 데 있어서 어머니만을 고려하였기 때문에 연구결과를 부모 전체로 일반화하는 데 한계가 있다. 최근 들어 아버지 역할과 부모공동양육이 강조되는 추세이므로 후속 연구에서는 아버 지의 양육스트레스, 부-자녀 상호작용 활동 및 양육행동 등도 측정할 필요가 있다.

본 연구는 위와 같은 제한점에도 불구하고 다음과 같은 의 의를 가진다. 첫째, 어머니의 양육스트레스가 학령진입기 아 동의 학업수행능력에 영향을 미치는 경로를 유아기에서 학령 기로의 전환기를 포함하여 종단적 인과관계를 살펴보았다는 점에서 의의가 있다. 둘째, 본 연구는 지금까지 크게 주목 받 지 못했던 초등학교 입학 직전 시기 어머니의 양육스트레스와 모-자녀 상호작용 활동 및 양육행동을 아동의 인지 및 학습 발 달의 선행 변인으로서 학문적 관심을 이끌어내었다. 양육스트 레스는 부모가 스트레스를 느끼는 것에서 그치는 것이 아니라 양육 관련 다수의 변인들과 연계되어 누적적이고 연속적으로 아동발달 전반에 영향을 미치므로 중요하게 다루어질 필요가 있다. 특히 자녀가 초등학교 입학을 앞둔 시기 부모는 인지학 습이 본격화되고 또래들과의 비교와 경쟁이 시작되면서 사교 육이나 선행학습 위주의 왜곡된 조기교육으로 인하여 유아기 와는 다른 차원의 양육스트레스를 경험할 수 있다. 따라서 유 아기에서 학령기로의 전환기에 해당하는 자녀를 둔 어머니들 을 대상으로 맞춤형 부모교육을 제공하고 가정환경의 어려움 으로 인해 교육적 지원이 충분히 이루어지지 않을 경우를 대 비해 학생들의 학습을 지원하고 향상시키기 위한 제도와 정책 마련을 위해 힘써야 할 것이다. 마지막으로, 본 연구는 학습준 비도와 학업수행능력에 대한 관심과 여러 시사점을 제시하였 다. 학습준비도와 관련하여, 학습에 대한 준비가 비단 인지.학 습적 영역만을 의미하는 것이 아니라 사회.정서적 측면을 아 우르는 보다 포괄적이고 전인적인 발달과 성장을 의미하는 개 념임을 강조하였다. 학업수행능력의 경우, 유아기부터 시작될 수 있는 교육격차 및 교육 불평등에 대한 관심을 이끌어냄으 로써 초등 저학년 아동의 학습부진, 학습지연 또는 학업중단 과 같은 중대한 문제에 대한 예방적 접근을 강조하였다. 특히 유아기 학습준비도의 중요성이 부각됨에 따라 학령진입기 아 동의 학업수행능력 증진을 위한 영유아보육/교육 기관의 역 할과 책임이 더욱 부각되었다. 이를 위하여 역량강화를 위한 교사교육과 영유아보육/교육 기관과 학교의 연계 및 협력 시 스템 구축을 통한 통합적 교육프로그램의 연구 및 개발에 대 한 필요성이 요구된다. 이와 같이 본 연구는 부모의 양육특성 을 포함한 가정환경과 영유아보육/교육 기관 및 공교육에 대
한 중요성을 강조하였으며, 아동발달 촉진을 위한 정책 마련 및 부모교육의 기초자료로 활용될 수 있을 것으로 기대된다.

\section{Notes}

This article is a part of the first author's doctoral dissertation submitted in 2021.

\section{Conflict of Interest}

No potential conflict of interest relevant to this article was reported.

\section{References}

\section{In English}

Akhtar, T., \& Bilal, S. F. (2018). Exploring the concept of school readiness amongst parents, teachers and principals of preschools children. Pakistan Journal of Psychological Research, 33(1), 149-175.

Anderson, R. E. (2015). Focusing on family: Parent-child relationships and school readiness among economically impoverished black children. Journal of Negro Education, 84(3), 442-456. doi:10.7709/jnegroeducation.84.3.0442

Bardack, S., Herbers, J. E., \& Obradović, J. (2017). Unique contributions of dynamic versus global measures of parentchild interaction quality in predicting school adjustment. Journal of Family Psychology, 31(6), 649-658. doi:10.1037/ fam0000296

Baumrind, D. (1991). The influence of parenting style on adolescent competence and substance use. The Journal of Early Adolescence, 11(1), 56-95. doi: 10.1177/0272431691111004

Bodovski, K., \& Youn, M. J. (2011). The long term effects of early acquired skills and behaviors on young children's achievement in literacy and mathematics. Journal of Early Childhood Research, 9(1), 4-19. doi:10.1177/1476718X10366727

Daviesa, S., Janusb, M., Dukub, E., \& Gaskin, A. (2016). Using the early development instrument to examine cognitive and non-cognitive school readiness and elementary student achievement. Early Childhood Research Quarterly, 35, 6375. doi:10.1016/j.ecresq.2015.10.002

Dotterer, A. M. (2012) Parenting, race, and socioeconomic status: Links to school readiness. Family Relations, 61, 657-670. 
doi:10.1111/j.1741-3729.2012.00716.x

Duncan, R. J., Schmitt, S. A., \& Vandell, D. L. (2019). Additive and synergistic relations of early mother-child and caregiver-child Interactions for predicting later achievement. Developmental Psychology, 55(12), 2522-2533. doi:10.1037/dev0000824

Erickson, S. J., Duvall, S. W., MacLean, P. C., Tonigan, J. S., Ohls, R. K., \& Lowe, J. R. (2018). Mother-child interactive behaviors and cognition in preschoolers born preterm and full term. Journal of Child and Family Studies, 27, 36873700. doi:10.1007/s10826-018-1196-z

Farmer, A. Y., \& Lee, S. K. (2011). The effects of parenting stress, perceived mastery, and maternal depression on parentchild interaction. Journal of Social Service Research, 37, 516525. doi:10.1080/01488376.2011.607367

Harewood, T., Vallotton, C. D., \& Brophy-Herb, H. (2016). More than just the breadwinner: The effects of fathers' parenting stress on children's language and cognitive development. Infant and Child Development, 26(2), 1-19. doi:10.1002/ icd. 1984

Harmeyer, E., Ispa, J. M., Palermo, F., \& Carlo, G. (2016). Predicting self-regulation and vocabulary and academic skills at kindergarten entry: The roles of maternal parenting stress and mother-child closeness. Early Childhood Research Quarterly, 37, 153-164. doi:10.1016/j.ecresq.2016.05.001

Marti, M., Merz, E. C., Repka, K. R., Landers, C., Noble, K. G., \& Duch, H. (2018). Parent involvement in the getting ready for school intervention is associated with changes in school readiness skills. Frontiers in Psychology, 9, 1-15. doi: $10.3389 /$ fpsyg.2018.00759

Martoccio, T. L., Brophy-Herb, H. E., \& Onaga, E. E. (2014). Road to readiness: Pathways from low-income children's early interactions to school readiness skills. Infants and Young Children, 27(3), 193-206. doi: 10.1097/IYC.0000000000000014

Murphey, D. A., \& Burns, C. E. (2002). Development of a comprehensive community assessment of school readiness. Early Childhood Research and Practice, 4(2), 1-12.

Murray, E., \& Harrison, L. J. (2011). The influence of being ready to learn on children's early school literacy and numeracy achievement. Educational Psychology, 31(5), 529-545. doi:1 $0.1080 / 01443410.2011 .573771$

Palermo, F., Carlo, G., Ispa, J. M., \& Squires, C. (2019). Latina mothers' mental health and children's academic readiness: Moderation by maternal education. Journal of Applied Developmental Psychology, 62, 260-269. doi:10.1016/ j.appdev.2019.04.002

Pianta, R. C., Nimetz, S. L., \& Bennett, E. (1997). Motherchild relationships, teacher-child relationships, and school outcomes in preschool and kindergarten. Early Childhood Research Quarterly, 12(3), 263-280. doi:10.1016/S0885-
2006(97)90003-X

Prendergast, S., \& MacPhee, D. (2018). Parental contributors to children's persistence and school readiness. Early Childhood Research Quarterly, 45, 31-44. doi:10.1016/j.ecresq. 2018.05.005

Russell, D. W., Kahn, J. H., Spoth, R., \& Altmaier, E. M. (1998). Analyzing data from experimental studies: A latent variable structural equation modeling approach. Journal of Counseling Psychology, 45(1), 18-29. doi:10.1037/00220167.45.1.18

Rydell, A.-M., Berlin, L., \& Bohlin, G. (2003). Emotionality, emotion regulation, and adaptation among 5-to 8-yearold children. Emotion, 3(1), 30-47. doi:10.1037/15283542.3.1.30

Sabol, T. J., \& Pianta, R. C. (2011). Patterns of school readiness forecast achievement and socioemotional development at the end of elementary school. Child Development, 83(1), 282-299. doi:10.1111/j.1467-8624.2011.01678.x

Treyvaud, K., Doyle, L. W., Lee, K. J., Ure, A., Inder, T. E., Hunt, R. W., \& Anderson, P. J. (2016). Parenting behavior at 2 years predicts school-age performance at 7 years in very preterm children. Journal of Child Psychology and Psychiatry, 57(7), 814-821. doi:10.1111/jcpp.12489

Weegar, K., Guérin-Marion, C., Fréchette, S., \& Romano, E. (2018). Child physical punishment, parenting, and school readiness. Infant and Child Development, 27(1), 1-22. doi:10.1002/icd.2050

\section{In Korean}

Bae, B.-R. (2018). Moderation effect and mediation effect analysis. Seoul: Cheonglam.

Cho, B., Lee, J., Lee, H., Kwon, H. (1999). Dimensions and assessment of Korean parenting style. Journal of the Korean Home Economics Association, 37(10), 123-133.

Hong, S. (2000). The criteria for selecting appropriate fit indices in structural equation modeling and their rationales. Korean Journal of Clinical Psychology, 19(1), 161-177.

Hong, S. (2009). Gogeubyeongubangbeomnon wokeusyap sirijeu6: Gujobangjeongsingmohyeong chogeup [고급연구방법론 워 크샵 시리즈6: 구조방정식모형 초급]. Seoul: S \& M Research Group.

Jang, W.-H., Kim, M.-J, Lee, J.-Y., \& Kwon, J.-A. (2018). The effect of parents' parenting stress and teacher efficacy on children's elementary school adjustment: A mediating effect of children's self-esteem. Korean Journal of Early Childhood Education, 38(4), 379-398. doi:10.18023/ kjece.2018.38.4.015

Kim, C.-I., \& Kwon, Y.-J. (2018). The effects of mother's behavior control trajectory on school adjustment, studying ability 
and subjective happiness for children. The Journal of Child Education, 27(3), 207-221.

Kim, J., \& Hong, S. (2019). Examining structural relationships among school readiness, academic achievement, self-esteem, and school adjustment. Journal of Education \& Culture, 25(3), 507-525.

Kim, J. H., Jung, H. S., Kim, J. M., \& Yi, S. H. (2012). Development of a Korean home environment scale for early childhood. The Journal of Child Education, 21(1), 77-92.

Kim, K. H., \& Kang, H. K. (1997). Development of the parenting stress scale. Journal of the Korean Home Economics Association, 35(5), 141-150.

Kim, M. (2008). An exploratory study of student's experience of transition from kindergarten to first grade. Education research studies, 39(1), 181-210.

Kim, M., Hu, Y., \& Wang, W. (2019). A longitudinal analysis of factors affecting language development in infants. The Journal of the Korea Contents Association, 19(3), 457-465.

Kim, M. S., \& Moon, H. J. (2005). Relationship between parenting stress and parenting efficacy on parenting behaviors in mother with young children. Family and Environment Research, 43(8), 25-35.

Kim, Y., Koo, J. Y., \& Kim, H. K. (2019). Longitudinal effects of mothers' parenting stress on children's academic achievement during the transition to school: The double mediation effects of home environment and school readiness. International Journal of Early Childhood Education, 39(3), 191-213.

Kim, Y.-M. (2019). The effects of mothers' parenting stress on chilren's learning readiness mediating effects of parent-child interactions and parental attitudes. Journal of the Korea Academia-Industrial cooperation Society, 20(12), 563-573. doi:10.5762/KAIS.2019.20.12.563

Kim, S. (2016). Gujobangjeongsik mohyeongui gibongwa hwakjang: MPLUS yejewa hamkke[구조방정식 모형의 기본과 확장: MPLUS 예제와 함께]. Seoul: Hagjisa.

Kwon, S., \& Lee, K. (2018). Effects of parent-child interaction and caregiving supports on the school readiness of preschoolers: Focusing on working mothers' job characteristics. Korea Institute of Child Care and Education, 12(2), 57-81. doi:10.5718/kcep.2018.12.2.57

Lee, E. J., \& Doh, H.-S. (2020). Longitudinal study on transactional and mediational relationships between mothers'happiness, parenting behaviors, and children's happiness: Focus on the transition from kindergarten to elementary school. Korean Journal of Child Studies, 41(4), 91-104. doi:10.5723/ kjcs.2020.41.4.91

Lee, J.-W., \& Cho, I.-K. (2019). The influence of parent-child interaction on the school readiness of their children: Focused on the mediating effect of co-parenting. The
Journal of Play Therapy, 23(1), 15-30.

Lee, Y., Kim, M., \& Lee, E. (2018). An analysis of influence of parents' family interaction and child's school readiness on child's social competence. The Journal of Korea Open Association for Early Childhood Education, 23(2), 45-67. doi:10.20437/KOAECE23-2-03

Lee, Y., Oh, B., Yoo, K.-B., Kwon, Y. D., \& Noh, J.-W. (2017). Correlation of the parenting stress and the child language. mathematical academic skills. Journal of the Korean Data Analysis Society, 19(3), 1571-1583.

Min, M. (2017). Verification of a structural model of the relationship between family resources, parent-child interaction, academic skills, and school readiness of preschoolers. The Journal of Korea Open Association for Early Childhood Education, 22(5), 1-19.

Park, K. J., \& Kwon, Y. H. (2002). Maternal behavior during mother-child problem solving : Effects of marital satisfaction, parenting stress, and attachment security. Korean Journal of Child Studies, 23(4), 53-70.

Park, S.-D., \& Chang, Y.-J. (2016). A study on effects of the interaction of children with parents, teacher and peers on their language and cognitive development. Journal of Education \& Culture, 22(2), 229-251.

Park, S. Y., Chun, J. A., \& Han, S. Y. (1996). Mother's parenting as related to child's temperament, mother's temperament, and mother's parenting stress. Family and Environment Research, 34(4), 203-215.

Song, Y. H. (2018). The effects of mothers' parenting stress and parenting behaviors on school readiness for preschool children (Master's thesis, Korea University, Seoul, Korea). Retrieved from https://dcollection.korea.ac.kr/public_resource/ pdf/000000080673_20210418221221.pdf

Yoon, J., Lee, M., \& Lee, Y. (2017). The effect of mother's parenting stress and expectation of child's school adaptation on school readiness as for their child's gender. Children's Media Research, 16(1), 131-155. doi: 10.21183/kjcm.2017.03.16.1.131

\section{ORCID}

Youn-Sun Won http://orcid.org/0000-0003-0066-5312

Hyun-Sim Doh http://orcid.org/0000-0002-7393-4520

Received October 30, 2021

Accepted December 13, 2021 